\title{
Green Chemistry in Agricultural Pest Management Programmes
}

\author{
Abhishek Kumar Dwivedy, Manoj Kumar, Neha Upadhyay and Dubey NK*
}

Centre of Advanced Study in Botany, Banaras Hindu University, Varanasi, India

\begin{abstract}
The article deals with recommendation of plant products as eco-friendly alternative of synthetic pesticides in agricultural pest management programme and emphasizes plant based green pesticides as important component in achieving ever green revolution in view of their high efficacy and favourable safety profile.
\end{abstract}

\section{Keywords: Plant products; Essential oils; Pest}

Agriculture has been extremely crucial for survival of human and associated animals since very long. It is also the basis of economic growth, particularly in the developing countries. Tropical and subtropical zone act as epicentre of food production because these areas provide seat for growth of multiple crops annually. Agriculture in tropical and sub-tropical belt is normally associated with attack of several pests due to congenial environmental conditions which sometime leads to tremendous loss of produce, thereby, creating catastrophic condition followed by famine in the concern area [1]. The situation worsens if these incidents appear in an area maximally dependent on agriculture.

Both pre- harvesting and post-harvesting stages are affected by pest but the post-harvest stages are mainly concern with the attack of fungi, insects and rodents [2]. During storage rodents and insects mainly attack seed grains, fungi and bacteria attack variety of substances including both raw and processed food materials. The hot and humid environment exponentially increases the occurrence frequency of the aforementioned microbes. Microbial contamination not only quantitatively deteriorates the stored commodities but sometime they produce secondary metabolite which are extremely harmful. Aflatoxins are few of that kind of mycotoxins secreted by Aspergillus flavus and Aspergillus parasiticus. Aflatoxins are reported hepatotoxic, carcinogen and mutagen [3] and causes aflatoxicosis in human being. About $25 \%$ of the world crops and 4.5 billion of the world population are facing direct risk of aflatoxin contamination [4].

For minimizing crop impairment due to pests, several chemical means are available and they have been in use for last seven decades and their utilization increased following the discovery of BHC (Benzene hexachloride), DDT, chlorinated cyclodienes, carbamates and organophosphates. These chemical pesticides tremendously increased the crop production and helped in success of green revolution. However, such synthetic pesticides have raised serious environmental problems and created hormonal imbalance, polluted ground water, having role in ozone depletion [5] and induced resistance in pests such as use of benzimidazole group of fungicides developed resistance in fungus and complicated the disease control practices. In view of negative impact of synthetic pesticides we need some green alternative of the synthetic pesticides for the management of pests.

History suggests the best alternative i.e., plant based pesticides; supported by the use of locally available plants against pest which is mentioned in Bible [6]. In India, onion bulbs have been used as insect repellent during storage of grains and we should also underline the tremendous use of neem (Azadirachta indica) as pesticide historically. In China also use of botanical pesticides is an ancient practice such as use of Melia azaderach as antihelmitic, use of Stemona sp root extract against lice and Artemisia sp against mosquitoes [7]. Other than the historical use, these botanicals are eco-friendly [8], renewable, systemic in action, safe for human and non target organisms, present in nature for millions of years without any adverse effect and having diverse biological effect, leading to minimum chance of resistance development in pests, make them a favourable substitute of synthetic pesticides.

Modern pesticide industry emphasizes the use of rotenone, pyrethrum and nicotine obtained from Derris, Chrysanthemum and Nicotiana respectively [9]. For centuries plants and insects have parallel pattern of evolution which made them interdependent. They communicate with each other through allelochemicals which exhibit different effects over insects such as repellent, antifeedant, oviposition deterrent, larvicidal or ovicidal effect. These allelochemicals are basically alkaloids, polyphenols, terpenes or isoprenoids [10]. Flavonoids obtained from Calotropis procera showed contact toxicity against Callosobruchus chinensis and ovicidal effect on bruchid eggs. Essential oils (EOs) of some plants belonging to family Lauraceae and Lamiaceae bear compounds such as eugenol, camphor, borneol, bornyl acetate, thymol and linalyl acetate. These compounds were found suitable as fumigant against adult of Sitophilus oryzae, Tribolium castenium and Rhyzopertha dominica which are common storage pest [11]. These plant products are potent antimicrobial also. Among different plant products, EOs of different plants have been reported efficacious to reduce the population of pests, biodeteriorating the post-harvest produce. A lot of reports are present on the antifungal and antibacterial properties of the EOs. Certain EOs such that Ocimum sanctum, Mentha spicata, Rosemarium officinale, Apluda mutica, Cymbopogon citratus, Ceasulia axillaris and Piper betel etc. have been reported to suppress aflatoxin production from Aspergillus flavus. Antioxdant property of these EOs is also useful in preventing lipid peroxidation of storage grains during storage which is a key factor for qualitative deterioration of stored grains and to minimize their shelf life.

Now a day's several plant based pesticides are available commercially for application in different areas such as carvone, derived from EO of Carum carvi and available with trade name of TALENT in the Netherland; a neem product with trade name SoluNeem ${ }^{\mathrm{TM}}$ containing azadirachtin and other bioactive component of neem and is highly effective as bio insecticide for field crops and vegetables; cinnamon oil based aphidicide/miticide/fungicide with trade name Cinnamite ${ }^{\mathrm{TM}}$ and Valero $^{\text {TM }}$ having cinnamaldehyde as active ingredient is also available [12]. Currently EcoSMART Technologies, an US based company,

*Corresponding author: N. K. Dubey, Professor of Botany, Centre of Advanced Study in Botany, Banaras Hindu University, Varanasi-221 005, India, Tel: +919415295765; Fax: +91542-2366402; E-mail: nkdubeybhu@gmail.com

Received October 07, 2015; Accepted November 11, 2015; Published November 17,2015

Citation: Dwivedy AK, Kumar M, Upadhyay N, Dubey NK (2015) Green Chemistry in Agricultural Pest Management Programmes. Med chem S2:005. doi: 10.4172/2161-0444.1000005

Copyright: (c) 2015 Dwivedy AK, et al. This is an open-access article distributed under the terms of the Creative Commons Attribution License, which permits unrestricted use, distribution, and reproduction in any medium, provided the original author and source are credited. 
Citation: Dwivedy AK, Kumar M, Upadhyay N, Dubey NK (2015) Green Chemistry in Agricultural Pest Management Programmes. Med chem S2:005. doi: 10.4172/2161-0444.1000005

\begin{tabular}{|c|c|c|c|c|}
\hline S No & Plant based pesticides & Source & Uses & Reference \\
\hline 1 & Carvone & EO of Carum carvi & Antimicrobial, repellent & {$[1,14]$} \\
\hline 2 & Neem, SoluNeem ${ }^{\mathrm{TM}}$ & Azadirachta indica & Bio insecticide, Antibacterial & {$[6,15]$} \\
\hline 3 & Rotenone & $\begin{array}{l}\text { Derris elliptica } \\
\text { Lonchocarpus utilis } \\
\text { Tephrosia sp. }\end{array}$ & Insecticide, Piscicide & {$[6,16]$} \\
\hline 4 & Pyrethrum & Chrysanthemum cinerariaefolium & Insecticide & {$[6,16]$} \\
\hline 5 & Nicotine & Nicotiana sp. & Insecticide & {$[17]$} \\
\hline 6 & Cinnamite $^{\mathrm{TM}}$ and Valero ${ }^{\mathrm{TM}}$ & EO of Cinnamon sp. & Aphidicide, miticide and fungicide & [12] \\
\hline 7 & EcoPCO $^{R}$ and Bioganic ${ }^{T M}$ & Eugenol and 2-phenethyl propionate & Insecticide & [12] \\
\hline 8 & Wasapower & Root extract of Wasabia japonica & Preservative & [13] \\
\hline 9 & DMC Base Natural & $50 \%$ EO from rosemary, sage, and citrus and $50 \%$ glycerol & Preservative & {$[19,20]$} \\
\hline 10 & Sabadilla & Seeds of Schoenocaulon officinale & Insecticide & {$[6,18]$} \\
\hline
\end{tabular}

Table 1: Popular plant based pesticides and their uses.

developed aerosol and dust based insecticides comprised of mixture of EOs compounds such as eugenol and 2-phenethyl propionate with trade name $\mathrm{EcoPCO}^{\mathrm{R}}$ and Bioganic ${ }^{\mathrm{TM}}$. Some EO-based preservatives are also popular such as "DMC Base Natural" comprised of 50\% EO from rosemary, sage, and citrus and 50\% glycerol. Another formulation "Wasapower" a developed by Sekisui Plastics Co. Japan, is comprised of root extract of Wasabia japonica [13] (A list of popular plant based pesticides is given in Table 1).

A lot of plant based products have been formulated for application as pesticides in green management of plant pests. These pesticides also act as green alternative of toxic synthetic pesticides. In view of their diverse effects and multi-component nature, plant based green pesticides would be highly suitable in pest management programme particularly against those which have developed resistance for single component pesticides. The formulation process of the botanical pesticides are little bit costly but this can be overcome by different means such as mass cultivation of the active plants and increasing efficacy by microencapsulating the active component. However, the plant based green pesticides are recognised as important component in achieving ever green revolution in view of their high efficacy, ecofriendly nature and favourable safety profile.

\section{Acknowledgements}

Authors are thankful to Council of Scientific and Industrial Research (CSIR), New Delhi, India for financial support.

\section{References}

1. Varma J, Dubey NK (2001) Efficacy of essential oils of Caesulia axillaris and Mentha arvensis against some storage pests causing biodeterioration of food commodities. Int J Food Microbiol 68: 207-210

2. Phillips TW, Berberet RC, Cuperus GW (2000) Post-harvest integrated pest management. Encycl Food Sci Technol, 2nd ed. Wiley, New York: 2690-2701.

3. Prakash B, Singh P, Kedia A, Dwivedy AK, Singh A, et al. (2012) Mycoflora and aflatoxin analysis of Arachis hypogaea L. and assessment of Anethum graveolens L. seed and leaf essential oils against isolated fungi, aflatoxin production and their antioxidant activity. J Food Safety 32: 481-491.

4. Dubey NK, Srivastava B, Kumar A (2008) Current status of plant products as botanical pesticides in storage pest management. J Biopesticides 1: 182-186.

5. Lee BH, Choi WS, Lee SE, Park BS (2001) Fumigant toxicity of essential oils and their constituent compounds towards the rice weevil, Sitophilus oryzae (L.). Crop Prot 20: 317-320.

6. Dubey NK, Shukla R, Kumar A, Singh P, Prakash B (2011) Global scenario on the application of natural products in integrated pest management programmes. Natural products in plant pest management 1: 1-20.

7. Yang RZ, Tang CS (1988) Plants used for pest control in China: a literature review. Econ Bot 42: 376-406.

8. Thilagavathi G, Kannaian T (2008) Application of Prickly chaff (Achyranthes aspera Linn.) leaves as herbal antimicrobial finish for cotton fabric used in healthcare textiles. Nat Prod Radiance 7: 330-334.
9. Secoy DM, Smith AE (1983) Use of plants in control of agricultural and domestic pests. Econ Bot 37: 28-57.

10. Regnault-Roger C, Philogène BJ (2008) Past and current prospects for the use of botanicals and plant allelochemicals in integrated pest management. Pharm Biol 46: 41-52.

11. Rozman V, Kalinovic I, Korunic Z (2007) Toxicity of naturally occurring compounds of Lamiaceae and Lauraceae to three stored-product insects. $J$ Stored Prod Res 43: 349-355.

12. Isman MB (2000) Plant essential oils for pest and disease management. Crop prot 19: 603-608.

13. Mishra PK, Kedia A, Dubey NK (2015) Chemically characterized Cymbopogon martinii (Roxb.) Wats. essential oil for shelf life enhancer of herbal raw materials based on antifungal, antiaflatoxigenic, antioxidant activity and favorable safety profile. Plant Biosyst-An International Journal Dealing with all Aspects of Plant Biology (In Press) 1-25.

14. Lazar EE, Jobling JJ, Benkeblia N (2010) Postharvest disease management of horticultural produce using essential oils: Today's prospects. Stewart Postharvest Rev 6: 1-9.

15. Danga SP, Nukenine EN, Fotso GT, Adler C (2015) Use of NeemPro®, a neem product to control maize weevil Sitophilus zeamais (Motsch.)(Coleoptera: Curculionidae) on three maize varieties in Cameroon. Agri Food Security 4: 18

16. Jacobson M, Crosby DG (1971) Naturally occurring insecticides. Naturally occurring insecticides.

17. Isman MB (2006) Botanical insecticides, deterrents, and repellents in moder agriculture and an increasingly regulated world. Annu Rev Entomol 51: 45-66.

18. Dayan FE, Cantrell CL, Duke SO (2009) Natural products in crop protection Bioorg Med Chem 17: 4022-4034

19. de Souza EL, Guerr NB, Stamford TLM, de Oliveira Lima E (2006) Spices: alternative sources of antimicrobial compounds to use in food conservation. Rev. Bras. Farm 87: 22-25

20. Mendoza-Yepe MJ, Sanchez-Hidalgo LE, Maertens G, Marin-Iniesta F (1997) Inhibition of Listeria monocytogenes and other bacteria by a plant essential oil (DMC) in Spanish soft cheese. J Food Safety 17: 47-55.

This article was originally published in a special issue, Green Chemistry handled by Editor(s). Dr. Michael Shapiro, University of Maryland Baltimore USA 